\title{
TEISÉ
}

\section{TEISININKO PROFESIJA IR ETIKA: RIBA TARP TEISĖS IR MORALĖS}

\author{
EGLE் RUZGYTE்
}

Vilniaus universiteto Teises fakulteto

Viešosios teisés katedros doktorantè

Vilnius University Faculty of Law

PhD student at Department of Public Law

Sauletekio al. 9, LT-10222 Vilnius

El.paštas egle.ruzgyte@tf.vu.lt

\section{Santrauka}

Teisininko profesijos atstovu statusas visuomenèje - itin reikšmingas, reikalaujantis ne tik aukšto intelekto, puikaus teisinio išprusimo, veikimo visuomeniniu interesu labui, bet ir etikos principus atitinkančio elgesio. Ne vien profesinis statusas savaime, bet ir nuostatos, itvirtintos teises aktuose, teisininkus ipareigoja laikytis etikos reikalavimu. Vis delto analizuojant profesine teisininku etika neapsieinama be ribos tarp teisés ir moralès klausimo, neretai jis lieka atviras.

Straipsnyje etikos požiūriu keliama teisèto profesionalaus teisininko elgesio pakankamumo abejone, siekiama pateikti teisininko profesijos ir etikos santykio analizę. Tam, kad bütu paaiškinta teisinés etikos išskyrimo reikšmè, iš pradžiu nagrinejjama etika bendraja prasme, vèliau pateikiama profesines etikos samprata. Taip norima atskleisti bendraja prasme suprantamos etikos virsma $\dot{i}$ teisinę. Kaip vieni svarbiausiu veiksniu, darančiu ịtaka teisininku profesinei etikai, nurodomos teisines ir moralinés nuostatos, taip pat asmeninis ir visuomeninis interesai. Šiu, dažnai vienas kitam prieštaraujančiu, dèmenu susidürimas vertinamas kaip galimybe atskleisti neetiško teisininku elgesio motyvus ir pasekmes. 
Reikšminiai žodžiai: teisininko profesija; teisinè etika; moralè; visuomeninis interesas; asmeninis interesas.

\section{Ivadas}

Sąvoka „teisininkas“ dažnai siejama su populiariausiomis - teisëjo arba advokato profesijomis. Šią sąvoką vaizdžiai paaiškintų, amerikiečių teisès filosofo Richardo A. Posnerio žodžiais tariant, šventikiškos teisininkų dramaturgijos apibūdinimas: aukšti suolai, mantijos, priesaikos, teisinis žargonas, retorika ${ }^{1}$. Visgi ṣ̨̌ simbolių rinkinį norètųsi papildyti dar vienu - etika. Taigi šios temos aktualumą galima paaiškinti keliais aspektais.

Pirmiausia, nūdienos teisiniai santykiai vis sudètingèja; problemos, su kuriomis susiduria teisininkai, nesprendžiamos atsietai nuo aksiologijos, socialinių aspektų, o profesinis teisininko vaidmuo suponuoja ypatingą jo statusą visuomenëje ir specifinį etikos supratimą, vertinimą. Būtų apmaudu manyti, kad iš teisininko profesijos atstovų reikalaujama tik puikaus teisinio išprusimo, bet ne etiško elgesio. Toks ypatingas teisininko statusas leidžia manyti esant visuomenès priklausomybę nuo teisininkų ir jiems perduotos teisingumo iggvendinimo funkcijos.

Tai, kad teisininko profesijos ir etikos analizè nèra vien tik teoriniu arba filosofiniu lygmeniu susiformavusi polemika, žymi etinių nuostatų ịtvirtinimas kodeksuose, tai yra privalomumo aspekto joms suteikimas. Ir net jei etika teisés mokslininkų, praktikų yra pamirštama, deja, apie ją neretai primena pasitaikantys teisininkų nusižengimai etikai, kurie neabejotinai sumenkina pagarbą ir pasitikejimą jais.

Poreikis analizuoti teisininkų etiką akademiniu lygmeniu jaučiamas dèl vis didejjančio asmenų, siekiančių igyti teisini išsilavinimą, skaičiaus, kuris, žinoma, lemia konkurenciją, o ši - galimai neetišką elgesį. Taigi šiame straipsnyje kaip leitmotyvas intuityviai keliamas klausimas:

${ }^{1}$ Posner, R. A. Jurisprudencijos problemos. Vilnius: Eugrimas, 2004, p. 18. 
ar teisètas profesionalaus teisininko elgesys turètų būti teisinès etikos maksima? Straipsnio objektu nurodomas teisininko profesijos ir etikos santykis. Pavadinimas mena, kad šio darbo tikslas nukreiptas $\mathfrak{i}$ teisininko profesijos ir etikos sąsajų, ribos tarp teisès ir moralès, dažnai tiesiogiai tapatinamos su etika, paieškas.

Diskusija apie teisès ir etikos ryši pirmiausia reikalauja teoriškai pagrịsti klausimą, kas yra etika bendrąja prasme ir kokia yra skirstymo ì profesinę bei teisinę etiką reikšmè. Profesinès ir teisinès etikos identifikavimas svarbus dèl teisinėms ir etinėms nuostatoms būdingo bendro - reflektyvumo - požymio. Kitas uždavinys yra atskleisti teisès ir etikos tarpusavio palaikymą, sąveiką ir galimus susikirtimus vertybinių nuostatų kontekste. Teisininkui, siekiančiam pamatinès (ne tik teisinès) vertybès - teisingumo, sunku priimti socialiai bendrą moralinị sprendimą, nes jis gali būti nesuderinamas su asmeninemis nuostatomis, o moralinès nuostatos prieštarauti teisinėms, ir atvirkščiai. Teisès ¡ikūnijamos vertybès yra persmelktos takoskyros tarp individo pripažìstamų ir visuomenès deklaruojamų normų. Mokslininkų diskusijos dèl visuomeninio intereso sampratos dar tebesitęsia, todèl atrodo natūralu, kad teisininkai visuomeninị interesą interpretuoja savaip ir kartais ji paverčia asmeniniu. Dèl šių prieštarų keliamos tokios abejonės: ar teisininkai, laikydamiesi teisinès etikos nuostatų, gali būti morališkai nepriklausomi, ar moralinès nuostatos dažnai nèra tiesiog teisinių nuostatų turinys, kokia sąsaja tarp teisininko moralinių nuostatų supratimo ir etiško elgesio pasirinkimo? Šių klausimų analizè gali padèti atskleisti teisininko profesiją demoralizuojančias priežastis, ịvertinti (ne)etiško teisininko elgesio motyvus ir pasekmes.

Reikia pabrèžti, kad moksliniu aspektu Lietuvoje matoma teisinès etikos analizès stoka, tik epizodiškai gvildenamos bendros teisininkų etikos problemos. Štai Tomas Berkmanas ir Edita Gruodytè vienoje publikacijoje vertina teisininkų etikos vertybių realumo ir modeliavimo aspektus. Julija Kiršiene ir Charlesas F. Szymanski straipsnyje aptaria vertybinių nuostatų, rengiant teisininkus universitete, galimybes, 
o Giedrẻ Lastauskienė analizuoja prieštaringą advokato profesijos pobūdį․ Užsienio šalių doktrinoje teisininkų etikos klausimai akademiniu lygmeniu analizuojami gana sistemingai ${ }^{3}$. Atsižvelgiant $\mathfrak{i}$ teisininkų veiklos produkto visuomenei svarbą, manytina, dèmesys analizuojamai temai turètų būti išskirtinis. Priešingu atveju, vyraujant nekintančioms etikos pažeidimų tendencijoms (pavyzdžiui, daugybė teisëjams ir advokatams iškeliamų drausmès bylų), patys teisininkai veikiausiai rizikuoja savo autoriteto nykimu.

\section{Etika bendrąja prasme}

Visuomenès raidos procese yra susiformavusios ištisos normų sistemos, nusakančios globaliai svarbius žmonių veiklos ir elgesio aspektus, tiesiogiai ar netiesiogiai nukreipiančios žmonių elgesị $\mathfrak{i}$ tam tikras vertybes ir tikslus. Tas sistemas apibendrintai galima vadinti teisès, etikos, moralès, rašytų ar nerašytų normų sistemomis ${ }^{4}$. Teisė savo socialinius uždavinius igyvendina remdamasi gretutinėmis socialinio reguliavimo disciplinomis. Šiame straipsnyje teisei antrina etika.

2 Kiršienè, J.; Szymanski, Ch. F. Vertybinių nuostatų ugdymo, rengiant teisininkus universitete, galimybės. Jurisprudencija. 2012, [t.] 19(4); Berkmanas, T.; Gruodytè, E. Teisininkų etikos vertybių realumo ir modeliavimo problemos. Teisés problemos. 2014, Nr. 85; Lastauskienè, G. Advokato profesija: prieštaringas jos pobūdis ir kontrolè. Jurisprudencija. 2013, [t.] 20(4). Paminètina ir tai, kad VDU Teisès fakulteto mokslininkų kolektyvas 2016 m. parengè monografiją ,,Teisininkų etika: nuo status quo pavyzdinio modelio link“ 2012-2014 metais vykdyto projekto „Teisininkų etikos reglamentavimo bei etinio ugdymo tobulinimo koncepcija“, finansuoto LMT, pagrindu.

3 Pearce, R. G. Revitalizing the Lawyer-Poet: What Lawyers Can Learn from Rock and Roll. Widener Law Journal, Vol. 14, 2005, p. 910; Pearce, R. G. Teaching Ethics Seriously: Legal Ethics as the Most Important Subject in Law School. Loyola University Chicago Law Journal, Vol. 29, No. 4, 1998; Gozon, M. Legal and Judicial Ethics, its Relevance Revisited. Arellano Law and Policy Review, Vol. 10, No. 1, 2009, p. 2-3.

4 Kuzmickas, B. Vertinimas, privalomybè, norma. Jurisprudencija. 2006, [t.] 9(87), p. 7 . 
Visuomenei vystantis kito įvairių gyvenimo sričių modeliai, tačiau jie visada egzistavo kaip tam tikra moralès norma. Manoma, kad moralès terminą I a. pr. Kr. pirmasis pradejo vartoti romėnų politikas ir filosofas Markas Tulijus Ciceronas, graikiškos kilmės žodžiui ethos ${ }^{5}$ lotynų kalboje jis rado atitikmeni - moralis ${ }^{6}$. Morales filosofijos terminą pirmasis taip pat pavartojo Ciceronas, jam suteikdamas tą prasmę, kurią Aristotelis teikè jo pasiūlytam etikos terminui ${ }^{7}$. Taigi dabartinejje filosofijoje pagrịstai morales terminas vartojamas ir tapatinamas su etikos terminu.

Lietuvių kalboje etikos sąvokai dar yra priskiriamas žodžio „dorove““ atitikmuo $^{8}$. Vis dèlto tokiam priskyrimui oponuojama dorovès apibūdinimu kaip objektyvios, pasižyminčios visuomeniškumu, bendrumu. O moralè suprantama priešingai - subjektyviai, individualiai ${ }^{9}$. Neabejotinų reikšminių sąsajų buvimą rodo etikos, moralès, dorovès sąvokų tapati vartosena etimologiniu požiūriu ${ }^{10}$. Atkreiptinas dėmesys, kad greta žodžio dorove vartojamas doros terminas, nusakantis derèjimą, privalejimą elgtis nustatytu būdu ir laikymąsi tokių, teisèje esminių,

5 Etika (gr. ethos - paprotys, ịprotis, būdas): 1. mokslas, tiriantis dorovę (moralę); 2. žmonių elgesio normų visuma. Vyriausioji enciklopedijų redakcija. Tarptautinių žodžiu žodynas [interaktyvus]. Prieiga per internetą: <http://www.tzz.lt/e/etika>

6 Moralè (lot. moralis - dorovinis), dorové, žmonių elgesị reguliuojančios normos ir principai. Vyriausioji enciklopedijų redakcija. Tarptautiniu žodžiu žodynas [interaktyvus]. Prieiga per internetą: <http://www.tzz.lt/m/moral\%C4\%97>.

Morale dar suprantama kaip: atitinkanti priimtinus bendro elgesio standartus; gero ir blogo žmonių elgesio normos (moralès normos), tinkamo ar netinkamo žmonių elgesio normos; kaip teisès ir pareigos, kurias sukuria morali teisė; kaip normos, susijusios su dorybèmis ar etika; kaip normos, sukeliančios psichologini efektą, susijusį su patikimai tinkamu elgesiu. Oxford English Reference Dictionary. Second Edition. Rivised. Oxford: Oxford University Press, 2003, p. 938.

7 Kanišauskas, S. Moralès filosofijos pagrindai. Vilnius: Mykolo Romerio universiteto Leidybos centras, 2009, p. 18, 30.

8 Lyberis, A. Sinonimu žodynas. Vilnius: Lietuvių kalbos institutas, 2002, p. 93, 264.

9 Pirmasis moralès ir dorovès terminus filosofijoje èmè skirti G. W. Hegelis. Hegel, G. W. Teisés filosofijos apmatai. Vilnius: Mintis, 2000, p. 83-91.

${ }^{10}$ Graikų kalboje sakoma etika, lotynų kalboje vartojamas žodis morale, o lietuvių kalboje-dorovè. 
principų kaip teisingumas, sąžiningumas, atsakingumas. Etikoje šie principai vadinami dorybėmis, vertybėmis, o teisèje jie igiję norminị pobūdị. Dorybingumas, moralumas sietinas su vidiniu sąžinès balsu ir su paprotinèmis elgesio normomis. Šiuo aspektu moralès normos yra nulemtos ne teisès, o moralè daro ịtaką tam tikros visuomenès priimtoms konkrečioms teisinèms nuostatoms.

Etikos santykio su morale kontekste pabrèžiama, kad moralè yra filosofinių etikos tyrimų objektas. Moralè yra vienas iš reikšmingiausių visuomeninių institutų, normatyviojo žmonių elgesio reguliavimo būdų ${ }^{11}$. Šioje srityje nagrinèjamas žmogaus elgesys, jo vertybès, keliami aksiologiniai, deramo elgesio klausimai, priešinamos gèrio ir blogio sampratos. Viena vertus, moraliniai veiksniai yra ypač svarbūs, jais grindžiamos kitos, su pasaulèžiūros nuostatų formavimu susijusios sritys, tokios kaip teisè, politika, ekonomika ir kt. Antra vertus, moralè yra socialinis reiškinys, dažnai pats savaime nepakankamas, stokojantis racionalaus paaiškinimo ${ }^{12}$. Būtent etikos uždavinys yra argumentuoti, pagrịsti moralinius aspektus. Šiam uždaviniui igyvendinti svarbus anksčiau minètas sąlyginis etikos ir moralès atskyrimo pagrindas moralès, kaip konkretaus žmogaus individualaus poelgio ar veiklos matas, pasireiškiantis formaliai atliekant tam tikrus veiksmus, siekiant tikslų ịvairiose ịpročių, papročių, gyvenimo būdo ar socialinėse situacijose. Etika yra tarsi disciplinuota moralès analizė, refleksija ${ }^{13}$, kuria siekiama kritiškai analizuoti, pateisinti žmonių santykius, taisykles.

Etikos apibrěžimo problematika (nevienalytė termino prigimtis), svarstymai apie etikos išsilaisvinimą iš mokslinio mąstymo rèmų kelia klausimą, ar etika apima visų žinių apie moralę kompleksą, ar ribojasi tik moralinių reikalavimų formavimu ir teigimu. Šiame darbe keliama

${ }^{11}$ Pruskus, V.; Briedis, M. Etika: vadovèlis. Vilnius: Technika, 2010, p. 8.

12 Boss, J. A. Analyzing Moral Issues. California: Mayfield Publishing Company, 1999 , p. 5.

${ }^{13}$ McCollough, E. The Moral Imagination and Public Life. Raising the Ethical Question. New Jersey: Chatham House, 1991, p. 10. 
prielaida, kad realiai egzistuojančių ir veikiančių etikos pasireiškimo formų analizė yra nagrinejjamos disciplinos integracijos ị kitus mokslus pagrindas.

Filosofo Ludwigo Wittgensteino nuomone, etika kartais nepasiduoda paverčiama mokslu, nes bet kokios pastangos tai daryti yra bandymas mokslinio mąstymo logiką priskirti sričiai, kuri savo prigimtimi tam nèra linkusi pasiduoti ${ }^{14}$. Visgi etikos nagrinèjimo objektas lemia plačias jos veikimo ribas. Pragmatinis etikos pobūdis gali būti atskleistas išskiriant etikos funkcijas:

- reguliavimo funkcija (etika, kaip visuomenès savireguliacijos irankis, padeda išlaikyti ir kritiškai vertinti elgesio imperatyvus, profesinius standartus);

- orientacinè funkcija (etikos mokslas ir teoriniai pagrindai, analizuojantys žmonių bendravimo normas, ịsipareigojimus, skatina tobulinti bendravimo igūdžius, priimti praktinius sprendimus);

- interpretavimo funkcija (privataus ir viešojo gyvenimo sferas etika ne tik aprašo, bet ir interpretuoja);

- švietimo funkcija (vienas iš etikos uždavinių - šviesti visuomenę, puoselèti vertybes, atsakingą bendravimą).

Diskurse apie etiką bendrąja prasme svarbi vertybių kategorija ${ }^{15}$, nes etika neịsivaizduojama be šio klausimo nagrinèjimo ${ }^{16}$. Objektai ir reiškiniai tampa vertybèmis tik dèl to, kad jie įtraukiami ił žmonių visuomenès būties sferas, todèl vertybès paprastai yra tokie nuo visuomenės priklausomi reiškiniai, kurie, tenkindami kokius nors žmogaus poreikius ir interesus, turi teigiamą reikšmę. Manytina, kad vertybè savaime svarbi ne kaip tam tikras moralès objektas, bet kaip paaiškinimas, kodèl žmogus, vadovaudamasis savo nuostatomis, įsitikinimais,

${ }^{14}$ Wittgenstein, L. A Lecture on Ethics. The Philosophical Review I, 1965, p. 9.

15 Remley, P. Jr.; Herlihy, B. Ethical, Legal, and Professional Issues in Counseling. New Orleans: Pearson, 2013, p. 3.

16 Jokubaitis, A. Vertybiu tironija ir politika. Vilnius: Vilniaus universiteto leidykla, 2012, p. 68. 
pasirenka atitinkamą elgesio modelį. Vertybès per žmogaus sąmonę veikia jo priimamus sprendimus, sudaro sąlygas laikytis arba nesilaikyti visuomenės primetamų nuostatų.

Nors visuotinio sutarimo tiek dèl pačių vertybių, tiek dèl jų priimtinumo nèra, visgi egzistuoja tam tikras „vertybių karkasas“, dèl kurio reikšmès visuomenè sutaria. Platono vertybių hierarchijos viršūnèje - teisingumas. Pasak Platono, tai aukščiausias moralinio pasaulio taškas. Teisingumo sąvoka plati, todèl joje galima išskirti savarankiškų prasmių - teisinį, socialinị ir etinị teisingumą. Etinio teisingumo ideja, manytina, yra susiformavusi anksčiausiai, palyginti su kitomis (socialinio, teisinio teisingumo idejomis). Teisių ir pareigų bendrumas, egzistuojantis kaip asmens vidinis įsitikinimas, îsipareigojimas veikti derinant savo ir kito asmens naudą, yra išreikštas etinio teisingumo, garantuojamas laisvu apsisprendimu. Svarbu pabrěžti, kad su etiniu teisingumu artimai susijęs teisinis. Pastarojo teisingumo atveju teisių ir pareigų bendrumui suteikiama aiški taisyklių forma, įtraukianti išorinị privalomumo aspektą. Taigi etinis teisingumas yra pirmesnis už teisinị: kai nepakanka laisvo apsisprendimo tinkamai elgtis, etinis teisingumas papildomas teisiniu ${ }^{17}$. Šią teisingumo idejjos raidą galima laikyti etikos integracijos ị teisès mokslą pavyzdžiu.

Etikos bendraja prasme apibūdinimas pirmiausia prasideda nuo ryšio su moralès, dorovès sąvokomis. Nors etimologiniu požiūriu šių trijų terminų bendrų sąsajų buvimas, plačios veikimo ribos neginčijamos, etika pasireiškia svaresne praktinio pritaikymo galimybe. Pozityvizmas, siūlydamas vertybes palikti anapus mokslinio pažinimo ribų, taip tik dar labiau sustiprino mintị apie etinio mąstymo išskirtinumą ir jo pritaikymą praktinėse sferose. Svarbus yra kiekvieno žmogaus santykis su vertybinėmis reikšmėmis, kurios yra tam tikras asmenybės išraiškos ir realizacijos gyvenime, visuomenèje ar profesinejje veikloje matmuo. XX a.

${ }^{17}$ Gumbis, J. Teisès filosofija: probleminiai aspektai. Konspektas [interaktyvus]. Prieiga per internetą: $<$ http://www.tf.vu.lt/dokumentai/Viesoji_teise/Paskaitu medziaga/Teises_filosofija_probleminiai_aspektai.pdf>, p. 56. 
etikos terminas imtas vartoti siekiant apibrèžti ir pagrịsti elgesio normas konkrečiose žmonių veiklos srityse ${ }^{18}$. Taip ir susiformavo teisininkų, politikų, medikų, žurnalistų ir kitų profesijų atstovų profesinė etika.

\section{Profesinè etika}

Bendrosios moralinès nuostatos apima ịvairius gyvenimo santykius: asmeninius, visuomeninius ir profesinius. Poreikis profesionaliai spręsti moralinius klausimus skatina etikos plètrą - ugdomas mokslinis požiūris ị vertybes pasitelkiant profesinę etiką ${ }^{19}$, iš kurios ir kilo taikomasis ${ }^{20}$ etikos aspektas. Akivaizdu, kad profesinė etika yra artima visuomeninei arba etikai bendrąja prasme. Gali kilti profesinès etikos išskyrimo prasmès arba reikalingumo klausimas, nors laikomasi nuostatos, kad vyraujančios vertybès yra bendros. Kita vertus, nepaisant visuomeniškai suprantamų vertybių, galimas jų grupavimas, skirstymas konkrečių profesijų atžvilgiu. Šiuo aspektu taip pat svarbu aptarti formalųji ${ }^{21}$ požiūrị i profesinę etiką.

Sąvoka profesija $a^{22}$ (lot. professio) reiškia darbinès veiklos rūšį, kuriai reikia specialaus pasirengimo ${ }^{23}$. Suprantama, kad etiką apibūdinus

${ }^{18}$ Kanišauskas, S. Moralès filosofijos pagrindai. Vilnius: Mykolo Romerio universiteto Leidybos centras, 2009, p. 21.

19 Profesinė etika - tam tikros profesijos žmonių, ypač tų, kurių darbas susijęs su kitais žmonėmis arba kurių veiklos produktas gali būti visuomenei moraliai reikšmingas, dorovès normos. Stonkus, S. Sporto terminu žodynas. 2-asis pataisytas ir papildytas leidimas. Kaunas: Lietuvos kūno kultūros akademija, 2002, p. 22.

${ }^{20}$ Kalenda, Č. Taikomoji etika: iškilimas ir ypatybès Lietuvoje. Filosofija. Sociologija. 2009, T. 20, Nr. 1, p. 56.

${ }^{21}$ Jibril, A.; Adelahu, Z. Legal Profession and Ethics. Teaching material. Chilot wordpress, 2009, p. 6.

22 Vyriausioji enciklopedijų redakcija. Tarptautiniu žodžiu žodynas [interaktyvus]. Prieiga per internetą: <http://www.tzz.lt/p/profesija $>$.

${ }^{23}$ Terminas ,profesija“ dar gali reikšti ịgyjamą specialybę - atitinkamų mokslo žinių ir praktinių igūdžių visumą, kurią ịsisąmonina žmogus, rengdamasis konkrečios profesijos darbui arba ịgydamas reikiamą kvalifikaciją. Bonz, B. Profesinis ugdymas ir kvalifikacija. Profesinis rengimas: tyrimai ir realijos. 1998, Nr. 1, p. 10. 
kaip profesinę jos sritis tampa kur kas siauresnè, nes profesinès etikos atveju daugiausia dèmesio skiriama pavienių profesijų atstovų (teisininkų, medikų, pedagogų ir kt.) elgesị formuojančioms nuostatoms ir pačiam elgesiui. Profesinę etiką galima suprasti dvejopai: kaip tam tikrų normų, standartų visumą, kuria turi vadovautis atskira profesinè grupe, ir etines problemas, kylančias praktinèje veikloje, arba kaip profesinių etikos normų mokymąsi.

Etiką vertinant kaip universalų abstrakčių taisyklių rinkinį, susiduriama su profesinès etikos reikalingumo dilema. Jeigu galima teigti, kad etika, susijusi su konkrečia profesija, nèra identiška visuomeninei, tuomet svarbus tokios - profesinès - etikos išskyrimo pagrindas. Tai, kad atskirų profesijų atstovų etika yra kilusi iš bendrąja prasme suprantamos etikos, iprastai neabejojama. Tačiau vieni autoriai teigia, kad profesijos atstovai, vykdydami jiems priskiriamas pareigas, turi vadovautis išskirtinai savo profesiniais interesais ir skirtingomis moralinemis nuostatomis, kiti autoriai oponuoja, kad užtenka vadovautis visuomenejje ịsivyravusiomis dorovès normomis ir atskira profesinè etika nereikalinga. Vis delto profesinio moralinio principingumo siekimas nèra paremtas vien tik asmeninėmis ar visuomeninėmis etinėmis nuostatomis. Žinoma, nẻ viena profesija negali iškelti tokių nuostatų, kurios šiurkščiai pažeistų bendras etikos normas. Šiuo atveju bet kuri profesija rizikuotų savo pačios autoriteto žlugimu. Bandymas suvienyti abu pirmiau minètus požiūrius leidžia pateikti išgrynintą profesinès etikos vaidmenį - ją reikètų suprasti kaip bendrosios suintensyvinimą, teikiant išskirtinị dèmesị atskirų profesijų atstovų elgesiui ir jị reguliuojančioms nuostatoms.

Etikos taikymas konkrečiai profesinei sričiai gali būti grindžiamas keliais aspektais. Pirmiausia, bet kurios profesijos atstovams jų etika yra aktualus praktinis klausimas, tačiau tam tikroms profesijoms (pavyzdžiui, teisininko, gydytojo) etinès nuostatos yra viena iš svarbiausių profesinių charakteristikų. Šis aspektas yra implikuotas esminių jų profesijoje vertybių (tokių kaip atsakomybès, teisingumo, sąžiningumo ir kt.) ir vidinio moralinio siekio rūpintis ne tik asmeniniais, bet ir 
visuomeniniais interesais. Minėtų profesijų atstovų veiksmai tiesiogiai susiję su visuomene, jos gerove, todèl etinių nuostatų laikymasis dažnai yra lemiamas veiksnys galimų neigiamų padarinių atžvilgiu. Be kita ko, svarbu pabrèžti, kad profesinės etikos specifiką formuoja pačių profesijų skirtumai. Nors tam tikrų profesijų atstovų elgesị lemia bendrai suprantama etinių nuostatų visuma, tačiau ji kur kas labiau modifikuojama konkrečioje profesinèje veikloje. Tai lemia profesinės veiklos reguliuojamų santykių savitumas, skirtingumas, visapusiškesnis konkrečių žmonių ịsitikinimų vertinimas, kvalifikaciniai reikalavimai.

Etikos taikymas taip pat grindžiamas etikos institucionalizavimo elementų $^{24}$ sistemos buvimu. Tokie elementai kaip etikos kodeksai, mokymai, igaliotų etikos tarnybų, komitetų veikimas suponuoja taikomąji etikos pobūdị konkrečioje profesijoje. Tačiau pernelyg formalus požiūris ị etiką - griežtas profesinès etikos sunorminimas, atskiroms profesijoms priskiriamų moralinių nuostatų grupavimas ${ }^{25}$ - gali paneigti etikos, kaip vertybinès kategorijos, buvimą. Pritartina pozicijai, kad tiek profesinèje, tiek kitose etikos srityse vertybès, perimtos internalizacijos būdu, lemia priemonių ir tikslų pasirinkimą siekiant teigiamų profesinių rezultatų. Etinių nuostatų nederètų painioti su techninèmis, organizacinėmis normomis, nes pastarųjų laikymasis nereikalauja asmens vidinių vertybinių nuostatų patikrinimo.

Taigi profesinė etika, būdama bendraja prasme suprantamos etikos tąsa, pasireiškia konkrečių, tam tikrai profesijai būdingų, vertybių sunorminimu. Nors visuomenėje ịvairios profesinès grupés vadovaujasi skirtingomis etinèmis nuostatomis ir taip neišvengiamai susiduriama su tokių nuostatų pliuralizmu, bendroji etika veikia kaip jų verifikavimo priemonè.

${ }^{24}$ Viena iš profesijos sampratų, teigianti, kad profesija - tai statusas, kuris pasiekiamas pasitelkiant įvairias veiklas. Šia samprata siekiama pagrịsti formaluji požiūrị ị profesinę etiką ir apibrèžti profesionalumui būdingus bruožus (pvz., profesinė asociacija, etikos kanonai, specialūs mokymai, kompetencijos tikrinimai ir kt.). Cotterrell, R. Teisés sociologija: jvadas. 2-asis leidimas. Kaunas: Dangerta, 1997, p. 230.

${ }_{25}$ Palidauskaitė, J. Etika valstybès tarnyboje: mokslinè monografija. Kaunas: Technologija, 2010, p. 101-174. 
Pamatiniai moralès pagrindai orientuoja tam tikrų profesijų atstovų veiklą, kad būtų pasiektas norimas praktinis rezultatas. Teisininko profesija yra kone daugiausia etinių klausimų nagrinejjanti profesija, todèl viena iš profesinès etikos sričių - teisinè etika - reikalauja išskirtinio dèmesio.

\section{Teisinè etika}

Šiuolaikinèje modernioje visuomenèje teisininko profesijos vaidmuo yra ypatingas. Teisineje valstybejje teisininkas yra tarsi moralès puoselètojas - reguliacinė struktūra, gebanti užpildyti spragą tarp valstybès sukurtų ịstatymų ir socialinio gyvenimo faktinių sąlygų ${ }^{26}$. Šiame kontekste teisès ir etikos tarpdalykinis pobūdis itin ryškus - teisinè eti$\mathrm{ka}^{27}$ yra daugiausia probleminių aspektų analizuojanti profesinès etikos sritis. Vien tai, kad teisininko profesija yra ịpareigota tiek teisiškai, tiek morališkai siekti tiesos ir teisingumo ${ }^{28}$, suponuoja neišvengiamą tarpdiscipliniškumo būtinybę, o norint ją pagrịsti būtina atskleisti teisès ir etikos ryši pradedant nuo teisininko profesijos sampratos. Be to, svarbu paaiškinti, kuo teisininkų etika (ne)išsiskiria iš kitų profesinès etikos sričių. Kitas klausimas, ar pagal pasirinktas etines pažiūras galima teisininko elgesi skirstyti $\underset{i}{i}$ atskirus vaidmenis.

Teisininko profesija demokratineje visuomeneje laikoma itin gerbiama, nes reikalauja aukšto intelekto, stiprių charakterio savybių ir noro veikti viešųjų interesų labui, juos derinant su privačiaisiais. Teisininko profesija ${ }^{29}$ yra apibūdinama kaip nuolatinė teisinės veiklos rūšis,

${ }^{26}$ Cotterrell, R. Teisès sociologija: jvadas. 2-asis leidimas. Kaunas: Dangerta, 1997, p. 115.

27 Teisine etika šiame kontekste yra teisininku etikos sinonimas.

${ }^{28}$ Kukaitis, M. Garbės negalima atimti, o tik prarasti. Justitia. 1999, Nr. 2(20), p. 18.

29 Pabréžtina, kad teisininko profesija yra platų veiklos spektrą apimanti profesinė veikla (teisejjo, advokato, prokuroro, notaro, antstolio, teisinių paslaugų teikejjo ir kt.). Sąvoka „,teisininkas“ nebūtinai reiškia teisès normų taikytoją, tai gali būti ir teisès tyrinètojas, teisès filosofas, teoretikas. Teisininku tampama igijus formalu išsilavinimą. Lietuvos Respublikos Vyriausybès nutarimas „Dẻl teisinių pareigybių sąrašo patvirtinimo“. Valstybès žinios. 2002, Nr. 82-3524. 
pagrịsta atitinkamomis žiniomis, sugebejjimais, igūdžiais ir mokejjimu ${ }^{30}$. Taigi esminis teisininko profesijos bruožas yra jo profesionalumas, apibūdinamas gerais profesiniais sugebejimais, aukšta veiklos kokybe. Pagrindinès teisinès idejjos, išplaukiančios iš teisininko profesionalumo, yra teisinès kvalifikacijos kèlimas, teisinių paslaugų kokybè ir profesinès teisinès etikos puoselèjimas. Vokiečių teisininkas ir sociologas Maxas Weberis iškèlè poreikị analizuoti profesines žinias, teisininkų vertybes, pažiūras ir išsiaiškinti, kaip tai formuojama praktiškai ir profesijos aplinkoje $\mathrm{e}^{31}$. Toks poreikis, anot mokslininko, pagrịstas pačia šios profesijos svarba teisei ir visuomenei. Svarbiausią teisininko bruožą taip pat akcentuoja Jungtinių Amerikos Valstijų profesinès etikos filosofas Markas Davisas, jis teisini profesionalumą apibūdina kaip savo profesijos iškèlimą i pirmą vietą (angl. putting your profession first) ir kartu savo mintị paaiškina, kad teisinė profesija nèra vien tik tam tikra bendrais interesais, bruožais apibūdinta profesija. Jo įsitikinimu, teigimas esant teisinès profesijos atstovu nereiškia vien tik teisinio išmanymo ar didelès patirties. M. Daviso manymu, būti teisininku reiškia laikyti save tokiu, kuris išpažista (angl. profess, satisfy) teisę, ìsipareigoja laikytis etikos. Profesionalumo tvirtinimas, pirmiausia, reiškia moralinị tvirtinimą teisininką saisto ne vien teisinès priedermès, nustatytos teisès aktuose, bet, svarbiausia - moralinès - suvoktos ir įsisąmonintos ${ }^{32}$. Galima teigti, kad etinès nuostatos pasireiškia teisininko profesionalumu; savo veikloje teisinès profesijos atstovas turi veikti laikydamasis teisès normų ir prisiimdamas atsakomybę; siekdamas teisingumo, privalo laikytis

${ }^{30}$ Kalesnykas, R. Teisininko profesinis rengimas: standartas, kokybė ir perspektyvos [interaktyvus]. Prieiga per internetą: $<$ http://www.elibrary.lt/resursai/Konferencijos/ KSMK_konf_medziaga/STRAIPSNIAI/R. Kalesnykas.pdf $>$.

31 Tokios pačios nuomonės laikèsi ir prancūzų sociologas E. Durkheimas. Jo teigimu, reikia išplèsti profesinès etikos sistemas, kad būtų apimtos ịvairios gyvenimo sferos. Panašią poziciją išreiškė R. Poundas ir K. Llewellynas, teigdami, kad teisinè profesija atlieka specifinị vaidmenị socialinèje integracijoje, skatina teisines vertybes.

${ }^{32}$ Davis, M. Professionalism Means Putting Your Profession First. The Georgetown Journal of Legal Ethics. Vol. 2, No. 1, 1998, p. 342. 
etikos ir garantuoti realią teisinę pagalbą. Pradžioje minèta tarpdalykinè teisès ir etikos sąsaja gali pagrịstai iškelti jųdviejų santykio problemą ${ }^{33}$. Tiek teisè, tiek etika (nors pastaroji yra laikoma seniausia socialinės reguliacijos forma) yra žmonių elgesị norminantys socialiniai reiškiniai. Etinès nuostatos yra abstraktaus ir platesnio pobūdžio, o teisinès - konkrečios, oficialiai paskelbtos. Kitas aspektas yra visuotinis teisinių nuostatų privalomas paisymas, pagrịstas galimu išoriniu valstybès įsikišimu ir atsakomybės taikymu. Šiuo požiūriu teisès ir etikos sąveika išryškèja taip: etikos normomis formuojamas pageidaujamas elgesys, o teisès normomis jis paverčiamas privalomu ${ }^{34}$. Visgi privalomumo aspekto suteikimas etinèms nuostatoms, reguliuojančioms konkrečią profesiją, jų ittvirtinimas teisès aktuose pašalina teisès ir etikos perskyrą. Pabrèžtina, kad etinių nuostatų laikymasis užtikrinamas abipuse nauda, vidiniu ịsitikinimu. Tačiau keliamas klausimas, ar teisinès etikos laikymasis yra taip pat nulemtas vidinio įsitikinimo, paskatos elgtis etiškai. Nors veiksmas, atliktas tik iš pareigos jausmo, savaime nereiškia, kad jis yra geras, vis dèlto teisinę etiką reikètų vertinti kaip išeitį formuojant sąmoningą, motyvuotą teisininko pasirinkimą elgtis deramai ${ }^{35}$.

Teisinès etikos reikalavimai gali būti traktuojami kaip vidinis savireguliacijos mechanizmas, kylantis iš sąmoningo vertybių

33 Šis santykis apibūdinamas etikos, kaip dar neinkorporuotos $i$ etikos kodeksus, kontekste.

34 Atkreiptinas dèmesys, kad ne visada etikos ir teisès normos sutampa. Pastarosios ne visada gali būti etiškos. Pvz., ịstatymai gali skatinti lygias teises (nedarbingų, neigalių žmonių teises) arba gali sumažinti teisių apimtị (patriotų teises). Be kita ko, daugelis etikos kategorijų, tokių kaip gèda, sąžinè, atgaila ir kt., yra už teisès ribų. Duquenoy, P.; Jones, S.; Blundell, B. G. Ethical, Legal and Professional Issues in Computing. London: Middlesex University Press, 2008, p. 6.

35 Teisingumas šiame kontekste suprantamas kaip universalus bendrasis teisès principas, reiškiantis moralinę žmogaus nuostatą ir kriterijų, pagal kurị vertinami visi asmenų poelgiai. Teisingumas ir neteisingumas nustatomi remiantis tokiais moralès kriterijais kaip gėris ir blogis, lygybė ir nelygybė, žmoniškumas ir nežmoniškumas ir t. t. Teisingumo siekis - tai protingos skirtingų interesų pusiausvyros siekis. Mikelėnas, V.; Vileita, A.; Taminskas, A. Lietuvos Respublikos civilinio kodekso komentaras. Kn. 1, Bendrosios nuostatos. Vilnius: Justitia, 2001, p. 75-76. 
internalizavimo ${ }^{36}$. Vertinant teisiškai, asmenybès bruožai ir veiklos motyvai nèra tokie svarbūs, o etikos požiūriu - priešingai - reikšmingas tiek teisininko elgesys, tiek ir jo asmeninès savybès. Neretai vadovavimasis teisès normomis yra prilyginamas etiškai veiklai, tačiau pripažįstama, kad teisètas elgesys yra etikos minimumas. Teisininkų etika reikalauja ne tik teisèto, bet ir aukštesnius standartus atitinkančio elgesio. Šis reikalavimas teisininkų etiką išskiria iš kitų profesijų etikos sričių. Teisinès etikos tyrinètoja Christine Parker teisininkų elgesị pagal pasirinktą vaidmenị visuomenèje siūlo skirstyti ị keturis modelius:

- rungtyniaujančio teisininko (angl. adversarial lawyer), kuris dirba išimtinai kliento interesais, dèl kliento jis turètų padaryti viską; šiam modeliui būdinga didesnis šališkumas klientui ir mažesnis kitos šalies ar trečiųjų asmenų interesams;

- atsakingo teisininko (angl. responsible lawyer), kurio esminè pareiga yra palaikyti teisingumą, visos teisès sistemos integralumą ir prireikus aukščiau kliento interesų iškelti visuomenès gerovę; čia teisininko moralinès nuostatos nèra siejamos su kliento interesais ir jo vaidmuo yra tarsi socialinès tvarkos visuomeneje patikètinio, sąžiningo ir teisingo, veikiančio pagal ịstatymus asmens;

- moralinio aktyvisto (angl. moral activist), kuris yra socialiai aktyvus, kritiškas ir skatinantis teisès reformas atsižvelgiant $\mathfrak{i}$ viešajj interesą; šiam modeliui svarbūs teisininko asmeniniai isitikinimai, nes aktyviai siekiama teisingumo; norima paveikti advokatus, kad šie moralines nuostatas ir viešąji interesą iškeltų aukščiau kliento interesų;

- rūpestingo teisininko (angl. ethics of care), kuris yra atsakingas žmonėms, palaiko gerus tarpusavio santykius, bet kartu siekia gauti daugiau pajamų; šis modelis grindžiamas abipuse nauda, asmenine ir santykių etika, - teisininkas privalo būti atviras,

${ }^{36}$ Palidauskaitè, J. Etika valstybès tarnyboje: mokslinè monografija. Kaunas: Technologija, 2010, p. 43. 
klientui išaiškinti galimas sprendimo pasekmes, alternatyvas ir leisti jam pasirinkti priimtiniausią variantą; šiuo modeliu puoselejjamas abipusis bendravimas, komunikacija, siekiama išvengti žalos ${ }^{37}$.

Kaip matyti iš pateiktų modelių, galima teigti, kad etika veikia teisininko elgesị pagal pasirinktus vaidmenis visuomenejje. Pastarieji trys modeliai leidžia lanksčiai modeliuoti teisininkų etikos procesus. Būtina akcentuoti kaitos visuomeneje ir joje vyraujančių nuostatų aspektą, veikiantị ir teisininkų elgesio modelius, nes egzistuoja didelè teisininkų darbo, pažiūrų ir aplinkos įvairovè.

Teisinès etikos neišskirtinumo aspektas yra tas, kad teisininkai, kurie laikosi visų įsipareigojimų (ir profesinių), nèra geresni negu paprasti (angl. ordinary) žmonès ${ }^{38}$. Kita vertus, galima ši aspektą laikyti teisinès etikos išskirtinumu. Būtų apmaudu manyti, kad visuomenè iš teisininkų tikisi tik nepriekaištingo teisès išmanymo ${ }^{39}$. Teisininkai turi išskirtinę privilegiją etikos principais reguliuoti savo veiklą ir kartu praktikuoti teisę. Šios privilegijos pagrindas yra teisininko profesija, kaip garantas visuomenei, kad teisininkai bus etiški ${ }^{40}$. Teisètumo reikalavimas išskirtinai teisininkui turètų būti savaime suprantamas. Edwardo A. Parsono požiūriu, teisininko profesija - tai ne tik socialinis veikimas, valdomas laisvo individų interesų žaismo, bet ir norminiai lūkesčiai, kuriuos lemia teisininko užimama pozicija visuomenejje. Anot jo, profesinị elgesị lemia konkrečios socialinès vertybės ir

${ }^{37}$ Parker, Ch. A Critical Morality for Lawyers: Four Approaches to Lawyers Ethics. Monash University Law Review. Vol. 30, No. 1, 2004, p. 56.

${ }^{38}$ Davis, M. Professionalism Means Putting Your Profession First. The Georgetown Journal of Legal Ethics. Vol. 2, No. 1, 1998, p. 344.

39 Remiantis legalizmo teorija, iš esmès vietoj etikos dominuoja tik teisinès taisyklès, o teisininkui nėra pasirinkimo svarstymams, kokios moralinès vertybès turètų skatinti jo elgesį, teisininkas - taisyklių išmanytojas ir vykdytojas. Berkmanas, T.; Gruodytè, E. Teisininkų etikos vertybių realumo ir modeliavimo problemos. Teisés problemos. 2014 , Nr. 85, p. 85.

${ }^{40}$ Kiršienè, J.; Szymanski, Ch. F. Vertybinių nuostatų ugdymo, rengiant teisininkus universitete, galimybès. Jurisprudencija. 2012, [t.] 19(4), p. 1329-1330. 
normos, kurios šią profesiją atskiria nuo kitų ir pabrèžia jos monopoliją - atsakomybę - ir savaiminị reguliavimąsi ${ }^{41}$.

Apibendrintai galima ịvardyti tokius teisininkų etikos ypatumus:

- išpažindamas profesiją (angl. profess), teisininkas savo veikloje remiasi sąžiningumu, pagarbiai elgiasi su kitais, laikosi savo žodžio, nesinaudoja negerbtinomis praktikomis;

- teisininkas turi oficialų visuomenès veikèjo statusą, reiškiantị jo nekvestionuojamą ištikimybę profesinei etikai;

- savo darbe teisininkas tiesiogiai kuria materialinès teisès vertybes.

Profesinė teisininkų etika vertinama kaip pamatinè teisinès profesijos viešojo ir savojo įvaizdžio išraiška ${ }^{42}$. Teisininko, kaip autoritetingo subjekto, statusas paaiškintinas jam visuomenès perduota esmine funkcija - teisingumo siekiu. Visgi pripažìstama, kad teisinis išsilavinimas nèra teisinès etikos garantas, o etiški sprendimai priimami ieškant suderinamumo tarp vertybinių ir teisinių nuostatų.

\section{Teisinès nuostatos versus moralinès nuostatos}

Teisinių ir moralinių nuostatų susikirtimas - viena iš teisininko profesijos atstovų sprendžiamų problemų. Nūdienos teisiniai santykiai darosi komplikuotesni, daugèja „sudètingų bylų“43 atvejų, kurie

${ }^{41}$ Cotterrell, R. Teisès sociologija: ịvadas. 2-asis leidimas. Kaunas: Dangerta, 1997, p. 229.

42 Šlapkauskas, V. Teisés sociologijos pagrindai: vadovèlis. Vilnius: Mykolo Romerio universiteto Leidybos centras, 2004, p. 559.

${ }^{43}$ Byla, reikalaujanti kelių alternatyvių sprendimų vertinimo, laikytina sudètinga. Tai bylos, kurias sprendžiant reikia iš kelių galimų teisès normų pasirinkti vieną ir išsamiai paaiškinti tikrąją jos prasmę arba rinktis iš kelių vertybių, principų, aiškinimo alternatyvų. Mikelènienè, D.; Mikelènas, V. Teismo procesas: teisès aiškinimo ir taikymo aspektai. Vilnius: Justitia, 1999, p. 22-23.

F. A. Hayeko teigimu, kartais teisininkui, siekiančiam išsiaiškinti teisingumą, gali tekti apeliuoti ị egzistuojančias moralès taisykles, tais atvejais, kai pačios teisès normos eksplicitiškai apeliuoja i moralès kategorijas. Hayek, F. A. Teise, ịstatymu leidyba ir laisvè. T. 2, Socialinio teisingumo miražas. Vilnius: Eugrimas, 1998, p. 87. 
dažnai nebèra sprendžiami izoliuotai nuo moralinių nuostatų. Šiuo požiūriu teisininkui tenka nagrinèti prioriteto klausimą - čia susiduria dvi konkuruojančios pozicijos: pozityvioji, besiremianti žmonių protu, paaiškinamais, teisès kurtais postulatais, ir prigimtinè, akcentuojanti vertybinių nuostatų svarbą. Nagrinejjant teisinę etiką, pozityviosios ir prigimtinès teisès teorijų susikirtimo klausimo išvengti negalima, juolab kad riba tarp etinių ir teisinių nuostatų praktikoje išnyksta. Teisininko požiūris i moralę, jos vertinimas, lemia sprendimą. Lygiai taip, kaip teisininko požiūris ị etiką lemia atitinkamą elgesio variantą. Kitaip tariant, teisininko požiūris ị etines nuostatas tiesiogiai veikia jo praktini pasirinkimą ir yra susijęs su jo kvalifikacija, išsilavinimu. Suprantama, kad požiūriai gali būti skirtingi, tačiau taikomoji etika profesinejje srityje remiasi anksčiau aptartu profesionalumo požymiu.

Dualistinè teisès prigimtis - jos normatyvumas ir vertybiškumas - laikytina ryškiausia pozityvizmo ir prigimtinès teisès teorijų prieštara. Prigimtinè teisès koncepcija išskiria teisę ir įstatymą. Pastarojo pamatas, anot šios doktrinos šalininkų, yra prigimtinè teisé, kuriai negali prieštarauti pozityvioji teisè. Šiame kontekste prigimtinę teisę reikia suprasti šiuolaikiškai, tai yra jos nekildinant iš Dievo ir nelaikant kieno nors duota teise, o vertinant kaip fundamentaliuosius moralès principus. Ronaldas Dworkinas teisès principus, etines nuostatas vertina kaip teisès esmę, tai grịsdamas teisejjų kuriamos teisès, aiškinant principus ir etines nuostatas, argumentu. Teisès aiškintojo tikslas yra rasti moralinị pozityviosios teisès pagrindimą ${ }^{44}$. Priešingai negu prigimtinè teisès teorija, teisinis pozityvizmas pripažįsta rašytinę, statutinę, tai yra pozityviąją, teisę ir neigia jos moralinę prigimtị. Reikia pabrèžti, kad esminiai teisinių nuostatų bruožai, išryškejję dèl teisinio pozityvizmo, yra jų vidinè logika, teisinis

${ }^{44}$ Mikelėnienè, D.; Mikelènas, V. Teismo procesas: teisès aiškinimo ir taikymo aspektai. Vilnius: Justitia, 1999, p. 34-35. 
apibrèžtumas, tikslumas. Tačiau didžiausias pozityvizmo trūkumas itin formalus požiūris ị teisę, eliminuojantis vertybines kategorijas ir visiškai nepagrindžiantis teisinių nuostatų kilmès, o kartu - jų savanoriško legitimumo ${ }^{45}$. Taigi matomas ryškus teisinio pozityvizmo poveikis teisininko profesijai: teisès mokslo išgryninimas, o vertybių palikimas etikos mokslui tapo rimtu teisininkų darbo trūkumu. Lietuvoje pozityvizmo įtaka akivaizdi: teismų sprendimuose vyrauja formalūs teisès aiškinimo metodai, o vertybinių aiškinimo kriterijų dažnai vengiama ${ }^{46}$.

Nepasitikejjimą prigimtine teisès teorija implikuoja nebaigtas jos pagrindimas. Esminiais šios doktrinos trūkumais laikytini moralinių nuostatų neempiriškumas, ontologinis nepagrịstumas. Kaip trūkumas nurodomas ir moralinių nuostatų reliatyvumas, leidžiantis jas traktuoti savaip, o tai suponuoja visuotinių moralinių nuostatų neigimą. Dar vienas moralei oponuojantis argumentas - mechanizmo, skatinančio subjektą laikytis moralinès pareigos, nebuvimas. Nepaisant nurodytų trūkumų, vertintinas moralinių nuostatų lankstumas, leidžiantis jas analizuoti kaip teisinio ir etinio diskurso plètojimo galimybę. Teisès doktrinoje pripažįstamas moralinių nuostatų pasireiškimas teisès principų pavidalu $^{47}$.

Tai, kad teisinių ginčų sprendimas nèra vien tik loginė operacija, per kurią pritaikomos teisinès nuostatos, patvirtina esminis teisès

${ }^{45}$ Griežti teisiniai imperatyvai, kurių laikymasis užtikrinamas sankcijų baime, konformistiniu elgesiu, atgrasančiu teisiniu pobūdžiu.

${ }^{46}$ Bendrosios teisès tradicijos šalyse (pvz., Jungtinèje Karalystejje) teismai vadovaujasi aukštesne teise nei įstatymas, - teisèjas, matydamas, kad įstatymo negalima pritaikyti, nes šis prieštarautų bendrosioms vertybėms, kurios yra aukščiau įstatymo, jo netaiko. O kontinentinès teisès tradicijos šalyse, kurioms priklauso Lietuva, veikiama kitaip - čia vyrauja statutinè teisè ir teisèjas žiūri, kaip tiksliau pritaikyti istatymą. Jekentaitė, L. Teisinio ir moralinio diskursų antitezè. Jurisprudencija. 2006, [t.] 9(87), p. 14.

${ }^{47}$ Barak, A. The Judge in a Democracy. New Jersey: Princeton University Press, 2006, p. 57-63. 
siekis - teisingumas ${ }^{48}$. Teisingumo principo nepatikrinus moralinèje dimensijoje, negali būti sèkmingai igyvendintas pagrindinis teisès tikslas. Kyla klausimas, ar teisinèms nuostatoms reikalingas moralinis pateisinimas. Anot R. Dworkino, kiekviena teisės norma, nusakanti, kokia yra teisẻ konkrečiu atveju, apima ir moralinị sprendimą, nes teisinès nuostatos yra teisingos, kai jos kyla iš geriausiai moralès požiūriu teisę pateisinančių principų visumos. Pritariant tokiam požiūriui, galima teigti, kad principais, kaip moralinėmis nuostatomis, verifikuojamos teisinès nuostatos. Teisininkai, aiškindami (kurdami) teisę, turi atsižvelgti ne tik ị teisès normas, bet gali (dažnai privalo) atsižvelgti ir ị moralines nuostatas ${ }^{49}$. Kita vertus, šiame kontekste paminètina būtinybė apie teisès principus kalbètis su visuomenės dalimi, nepriklausančia teisininkų luomui ${ }^{50}$. Nūdienos teisininkai neretai manipuliuoja minètais teisès principų trūkumais, taip juos paversdami antivertybėmis. Teisès principai, išreikšdami visuomenèje ịsivyravusias vertybes, turètų būti teisès sistemos elementas, grandis, jungianti visuomenę ir teisininkus. Taip galima tikètis teisingo principų interpretavimo. Deklaruojamas moralinių nuostatų neobjektyvizmas, reliatyvizmas yra viena iš teisinio nihilizmo, nepasitikejimo teise ir teisininkais priežasčių.

Teisès principus neabejotinai galima vertinti kaip teisinio ir etinio diskurso plètojimo galimybę. Kai kalbama apie sudètingos bylos sprendimą, vien tik normos raidès pateisinimo nepakanka. Šị nepakankamumą gali padèti kompensuoti racionalus ir argumentuotas rèmimasis teisès principais, o tai reiškia moralinių nuostatų ị teisę ịsileidimą. Nors egzistuoja skirtingas prigimtinès teisès teorijos ir pozityvizmo vertinimas teisès susaistymo moralinèmis nuostatomis atžvilgiu, vis dèlto

${ }^{48}$ Lastauskienè, G. Teisès tikslai - spekuliacijos įrankis ar argumentavimo priemonè? Teise. T. 77 (2010), p. 30, 32.

49 Spruogis, E. Teisès aiškinimo probleminiai aspektai. Jurisprudencija. 2006, [t.] $8(86)$, p. 58.

${ }^{50}$ Lastauskienè, G. Korektiško teisès principų taikymo prielaidos. Teisè. T. 85 (2012), p. 47. 
principų svarba pripažįstama. Tai ne kartą patvirtino vadinamųjų tranzitinio (istorinio) teisingumo bylų nagrinejjimas, ypač kai buvo vertinama Vokietijos slaptųų tarnybų informatorių veikla ir suabejota tuomečių pozityvizmo deklaruojamų normų „teisingumu“51. Šiuo atveju Vokietijos teismai iš esmès rèmési moralès principais, apeliuodami ị sąžiningumą ir teisingumą. Žinoma, rèmimasis vien teisès principais sprendžiant sudetingas bylas vertintinas kritiškai, nes taip gali būti pažeisti asmenų teisèti lūkesčiai, teisètumas. Todẻl teisès principai turètų būti pasitelkiami kaip normų turinio nustatymo, patikrinimo ir teisinio argumentavimo stiprinimo, plètojimo priemone $\dot{~}^{52}$. Visgi akivaizdu, kad teisinio pozityvizmo reikštas moralinių nuostatų izoliavimas yra neįmanomas, - tai pagrindžia kiekvienoje teisès sistemoje imanentiškai egzistuojančių moralinių nuostatų visuma. Taigi teisininkams principų vertinimas kelia sudètingą užduotị ir kartu pareigą tinkamai interpretuoti ir igyvendinti moralines nuostatas praktikoje. Čia svarbu pabrèžti, kad teisininkų elgesys taip pat reglamentuojamas etikos principų pavidalu, o vyraujančios teisès sampratos požymiai leidžia prognozuoti teisei reikšmingų veiksmų rezultatyvumą ${ }^{53}$, analizuojamos temos aspektu - teisininkų (ne)etišką elgesį.

Apie teisingą teisès aiškinimą ir teisininko priimamą sprendimą negalima kalbèti jų nepagrindžiant tam tikromis moralinèmis nuostatomis. Vis dèlto, kad toks sprendimas būtų paremtas abipusiškai - teisinėmis ir moralinėmis nuostatomis, būtinas jųdviejų ryšys. Pozityvioji teisė, nesąveikaujanti su morale, verčia teisininką priimti neteisingą, amoralų sprendimą. Šiuo požiūriu, pasak V. Mikelėno, neteisingumas galimas dèl dviejų priežasčių: dèl pozityviosios teisès neteisingumo

${ }^{51}$ Simmonds, N. E. Law as a Moral Idea. Oxford: Oxford University Press, 2007, p. 37.

52 Lastauskienè, G. Korektiško teisès principų taikymo prielaidos. Teisè. T. 85 (2012), p. 59.

${ }^{53}$ Lastauskienė, G. Vertybiškai neutrali teisès samprata. Jos ženklai Lietuvos teisinèje mintyje ir praktikoje. Teisés problemos. 2006, Nr. 2(52), p. 8. 
arba dèl teisininko nekvalifikuotumo ar nesąžiningumo ${ }^{54}$. Gedimino Mesonio ir Kazimiero Meiliaus manymu, teisininkui, priimančiam teisinius sprendimus, rèmimasis moralinių vertybių sistema yra fundamentalus, taip pat nepamirštant kvalifikacinio teisininko profesijai keliamo aspekto ${ }^{55}$. Galima teigti, kad teisininko profesionalumas yra pagrịstas ir dalykine kompetencija, ir jo sąžiningumu.

Teisinis ir etinis diskursas neitmanomas be teisininko dėmesio moralinèms nuostatoms, nes racionalus jų taikymas praktikoje reikalauja sąmoningo supratimo ${ }^{56}$. Teisininkų etika ir etiškumas akcentuoja principų turejjimą ir jų laikymąsi. Moralumas šiame kontekste vertinamas kaip asmeninė atsakomybė už pasirinktus principus ir kritiškas reiklumas tradiciniams principams bei ịprastiems elgesio standartams. Vis dèlto išimtinai tik teisininkams pripažinta teisè spręsti, kas moralu ar nemoralu, suponuoja priklausomybę nuo teisininkų ir jų supratimo apie asmeninių, visuomeninių interesų sąveiką.

\section{Visuomeninis interesas versus asmeninis interesas}

Teisès ir moralès susidūrimas neišvengiamas. Vis dèlto kyla ir kita problema: kokiomis vertybinèmis nuostatomis teisininkui reikètų

${ }^{54}$ Pasak D. Mikelėnienès ir V. Mikelèno, bet kuris teisinis klausimas kartu yra moralès klausimas, tačiau etikas ir teisèjas vadovaujasi ne visai tapačiais standartais. Nors abu remiasi moralès nuostatomis, teisèjui pirmiausia sprendimą reikia grịsti teisès normomis, o šios ne visuomet atitinka moralès nuostatas, todèl teisèjai turi igyvendinti teisingumą ir materialiuoju, ir formaliuoju aspektu. Mikelènienė, D.; Mikelėnas, V. Teismo procesas: teisès aiškinimo ir taikymo aspektai. Vilnius: Justitia, 1999, p. 44.

${ }^{55}$ Mesonis, G.; Meilius, K. Moralès normos konstituciniuose teisiniuose santykiuose. Jurisprudencija. 2002, [t.] 31(23), p. 10.

${ }^{56}$ R. A. Posneris, klausdamas, ką moralè gali pasiūlyti teisei, kartu abejoja moralès reikšme teisei ir teigia, kad kalbos apie moralę suponuoja metadiskursą, nes, pasak jo, moralinès žinios pirmiausia yra patikrinamos intuicija, labiau linkusia nukrypti i šoną negu intuicija dèl fizinio pasaulio. Veikiausiai galima tokiam požiūriui oponuoti klausimais dèl moralès kilmès ir teisès, kaip fizinio pasaulio objekto, tikrumo. Posner, R. A. Jurisprudencijos problemos. Vilnius: Eugrimas, 2004, p. 292. 
vadovautis - ar asmeninėmis, ar visuomeninėmis? Atsakymą galima pagrịsti teisès, kaip visuomenines vertybes ịkūnijančio reiškinio, argumentu. Teisejjo profesijos atstovų atžvilgiu konkretesnị atsakymą pateikia Lietuvos Respublikos Konstitucijos 109 straipsnio 4 dalis, kurioje itvirtinta, kad teismas priima sprendimą valstybès, tai yra visuomenès, vardu. Tačiau teisèjas pirmiausia turi žinoti, kas yra visuomeninis interesas $^{57}$ ir ji teisingai suprasti, todèl labai svarbus asmeninio ir visuomeninio interesų atpažinimas.

Visuomeninis interesas socialiniu požiūriu yra konstitucinè vertybe $\dot{e}^{58}$. Šis teiginys suponuoja visuomeninị interesą esant ir moraline, visuotinai svarbia, ir teisine vertybe. Vadinasi, teisininkų dėmesys aptariamai vertybei turi būti išskirtinis. Nei teisès teorija, nei teismų praktika iki šiol nepateikè aiškių objektyvių norminių kriterijų, nusakančių visuomeninį interesą, todèl nėra keistas ir subjektyvus elementas, leidžiantis visuomeninị interesą vertinti labiau kaip socialinę negu teisinę kategoriją. Šiuo požiūriu Konstitucinis Teismas savo išaiškinimuose pabrèžia, kad viešojo intereso ịgyvendinimas yra viena svarbiausių visuomenès egzistavimo ir raidos sąlygų ${ }^{59}$, ir viešąji interesą traktuoja kaip visos visuomenès ar jos dalies interesą (taip pat ir individualaus asmens), grindžiamą pamatinėmis visuomenès vertybėmis, kurios yra itvirtintos, saugomos ir ginamos Konstitucijos. Konstitucinis Teismas įvardija tokias visuomenines vertybes kaip visuomenès atvirumas, darna, teisingumas, asmens teisès ir laisvès,

57 Vartojama sąvoka „visuomeninis interesas“ yra sąvokos „viešasis interesas“ sinonimas. Sąvokų tapatumą pripažįsta ir Lietuvos Respublikos Konstitucinis Teismas. Lietuvos Respublikos Konstitucinio Teismo 2005 m. gegužès 13 d. nutarimas ,Dèl Lietuvos Respublikos medžioklès įstatymo 7 straipsnio 2 dalies, 8 straipsnio 1, 9, 10 dalių, 13 straipsnio 2 dalies, 18 straipsnio 7 dalies ir 22 straipsnio 3, 6, 7 dalių atitikties Lietuvos Respublikos Konstitucijai“. Valstybès žinios. 2005, Nr. 63-2235.

${ }^{58}$ Lietuvos Respublikos Konstitucinio Teismo 1997 m. gegužès 6 d. nutarimas „Dèl Lietuvos Respublikos valdininkų ístatymo 16 straipsnio pirmosios dalies 2 punkto atitikimo Lietuvos Respublikos Konstitucijai“. Valstybès žinios. 1997, Nr. 40-977.

59 Ibidem. 
teisès viešpatavimas ir kita ${ }^{60}$. Antra vertus, Konstitucinis Teismas taip pat pažymi, kad atskiro asmens interesas taip pat yra konstitucinè vertybė, todèl visuomeninis interesas, kaip bendrasis, turi būti suderintas su individualiu ${ }^{61}$. Analizuojant visuomeninio intereso svarbą teisininko profesijai, aktualus $2004 \mathrm{~m}$. gegužès $25 \mathrm{~d}$. Konstitucinio Teismo nutarimas, kuriame nurodoma, kad Konstitucija yra grindžiama universaliomis, nekvestionuojamomis vertybėmis, tarp kurių išskiriamos pagarbos teisei, valdžios galių ribojimo, valdžios ịstaigų priedermès tarnauti žmonėms, atsakomybės visuomenei, teisingumo,

${ }^{60}$ Lietuvos Respublikos Konstitucinio Teismo 2006 m. rugsèjo 21 d. nutarimas „Dèl Lietuvos Respublikos administracinių bylų teisenos įstatymo 85 straipsnio 3 dalies (2000 m. rugsèjo 19 d. redakcija), 139 straipsnio 2, 3 dalių (2000 m. rugsèjo $19 \mathrm{~d}$. redakcija), Lietuvos Respublikos baudžiamojo proceso kodekso 306 straipsnio (2004 m. liepos $8 \mathrm{~d}$. redakcija), 308 straipsnio (2006 m. birželio $1 \mathrm{~d}$. redakcija) 2 dalies (2002 m. kovo $14 \mathrm{~d}$. redakcija), 324 straipsnio 12, 13 dalių (2002 m. kovo 14 d. redakcija), 377 straipsnio (2004 m. liepos 8 d. redakcija) 9 dalies (2002 m. kovo $14 \mathrm{~d}$. redakcija), 448 straipsnio 7 dalies (2002 m. kovo $14 \mathrm{~d}$. redakcija), 454 straipsnio 5, 6 dalių (2002 m. kovo 14 d. redakcija), 460 straipsnio 4, 5 dalių (2002 m. kovo 14 d. redakcija), Lietuvos Respublikos civilinio proceso kodekso 268 straipsnio 3 dalies (2002 m. vasario 28 d. redakcija), 285 straipsnio 2, 5 daliu (2002 m. vasario $28 \mathrm{~d}$. redakcija), 286 straipsnio 1 dalies (2002 m. vasario $28 \mathrm{~d}$. redakcija), 288 straipsnio 4 dalies (2002 m. vasario 28 d. redakcija), 289 straipsnio 2 dalies (2002 m. vasario $28 \mathrm{~d}$. redakcija), 303 straipsnio 2 dalies (2002 m. vasario 28 d. redakcija), 320 straipsnio 2 dalies (2002 m. vasario $28 \mathrm{~d}$. redakcija), 325 straipsnio 2, 3 dalių (2002 m. vasario $28 \mathrm{~d}$. redakcija), 358 straipsnio 2, 3 dalių (2002 m. vasario 28 d. redakcija) atitikties Lietuvos Respublikos Konstitucijai, taip pat dèl pareiškejjo - Seimo narių grupès prašymo ištirti, ar Lietuvos Respublikos teismų ístatymo 119 straipsnio 2 dalies 1 punktas (2002 m. sausio $24 \mathrm{~d}$. redakcija), 119 straipsnio 5 dalis (2002 m. sausio 24 d. redakcija), 120 straipsnio (2003 m. sausio 21 d. redakcija) 1 punktas (2002 m. sausio 24 d. redakcija), Lietuvos Respublikos Prezidento 2003 m. vasario 19 d. dekretas Nr. 2067 ,Dèl apygardos teismo teisèjo igaliojimų pratęsimo“, Lietuvos Respublikos Prezidento 2003 m. birželio 18 d. dekretas Nr. 128 ,Dèl apygardų teismų skyrių pirmininkų skyrimo“ ta apimtimi, kuria nustatyta, kad Vilniaus apygardos teismo teisejjas Konstantas Ramelis skiriamas šio teismo civilinių bylų skyriaus pirmininku, neprieštarauja Lietuvos Respublikos Konstitucijai““. Valstybès žinios. 2006, Nr. 102-3957.

61 Ibidem. 
teisinès valstybès ir pagarbos žmogaus teisėms vertybès ${ }^{62}$. Sprendžiant iš Konstitucinio Teismo nutarimuose pateiktų išaiškinimų galima teigti, kad: pirma, vertybès pripažìstamos kaip visuomeninès; antra, visuomeninis interesas yra išreikštas kaip vertybinẻ konotacija, igaunanti norminị pobūdị; trečia, asmeninis interesas - taip pat vertybè, tačiau turinti derèti su visuomeniniu; ketvirta, teisininkas šiame kontekste turètų būti suprantamas kaip visuomeninių vertybių sergètojas ir gynejjas. Remiantis šiais apibendrinimais, visuomeninio ir asmeninio interesų susidūrimą galima vertinti kaip teisinio ir etinio diskurso plètojimą.

Teisinejje valstybejje teisininko profesijos atstovo vaidmuo yra viešas, tačiau tuo pačiu metu teisininkas nenustoja būti privatus asmuo. Tai reiškia galimą interesų konfliktą, kai susiduria suinteresuotumas tinkamai atlikti visuomenines pareigas su privačiomis (pavyzdžiui, ekonominėmis) intencijomis. Kitaip tariant, interesų konfliktas kyla dèl teisininko netinkamo santykio su visuomeniniu interesu arba naudos siekiu visuomenès intereso sąskaita pažeidžiant teisines arba etines nuostatas ${ }^{63}$. Pabrèžtina, kad viena iš profesinès etikos nesilaikymo priežasčių yra konflikto tarp viešųjų ir privačių interesų neidentifikavimas. Asmeninio ir visuomeninio interesų konfliktas pasireiškia šališkumu, subjektyviu ir nesąžiningu sprendimų prièmimu, konfidencialumo issipareigojimų, lojalumo pažeidimu ir kitokiu netinkamu pareigų atlikimu ir tiesiogiai siejasi su teisininko atsakomybe, jo bendraja ir profesine etika. Teisininkų etika visuomeniniu požiūriu svarbi dèl kelių priežasčių. Pirmiausia, demokratinè teisinė valstybė remiasi pasitikèjimu - visuomenè iš teisininkų tikisi prioritetinio rūpesčio Konstitucijoje ịtvirtintomis vertybėmis. Kita svarbi priežastis yra susijusi su

${ }^{62}$ Lietuvos Respublikos Konstitucinio Teismo 2004 m. gegužès 25 d. nutarimas „Dèl Lietuvos Respublikos Prezidento rinkimų įstatymo $1^{1}$ straipsnio (2004 m. gegužès 4 d. redakcija) ir 2 straipsnio 2 dalies (2004 m. gegužès 4 d. redakcija) atitikties Lietuvos Respublikos Konstitucijai“. Valstybès žinios. 2004, Nr. 85-3094.

${ }^{63}$ Moore, A.; Cain, D. M.; Loewenstein, G.; Bazerman, H. M. Conflicts of Interest. Cambridge: Cambridge University Press, 2005, p. 1-15. 
aukštesnių (negu eilinių piliečių) moralinių standartų laikymusi tiek profesiniame, tiek asmeniniame gyvenime ${ }^{64}$.

Teisininko profesiją iš kitų profesijų išskiriantis bruožas yra jo konstitucinis įsipareigojimas puoseleti ir ginti visuomenines vertybes. Akivaizdu, kad analizuojama problema reiškia ne tik teisinị ir etinį, bet taip pat visuomeninị ir asmeninị konfliktus. Asmeninio intereso iškèlimas virš visuomeninio arba netinkamas pastarojo identifikavimas suponuoja neetišką elgesị ir visuomenès nepasitikejjimą teisininkais. Taigi visuomeninio intereso kategorija turètų būti suprantama kaip potenciali suvaržymo doktrina, ribojanti viešosios ir privačios galios ekscesus $^{65}$, nurodanti esmines vertybes ir sauganti demokratinius lūkesčius.

\section{Išvados}

1. Etimologiškai etika pagrịstai tapatinama su morale, vertybinèmis kategorijomis, tačiau bendrąja prasme suprantamos etikos pritaikymas tokioje praktineje sferoje kaip profesija lemia etikos turinio kitimą, jos ribų siaurèjimą ir suponuoja etines nuostatas esant viena iš svarbiausių profesinių charakteristikų. Teisinè etika, kaip profesinès etikos sritis, yra siejama su teisininko profesionalumu, kompetencija, teisètu elgesiu, - šie aspektai leidžia objektyviai ịvertinti teisininko profesijos atstovų elgesí.

2. Pagrindiniais veiksniais, darančiais ịtaką teisininko profesinei etikai, laikytini teisinès ir moralinès nuostatos, asmeninis ir visuomeninis interesai. Prioriteto pasirinkimas šių, dažnai vienas kitam oponuojančių, elementų atžvilgiu gali lemti galutinę išvadą, kad elgesys laikytinas (ne)etišku. Teisininko profesijos ir etikos kontekste asmeninis interesas, kaip subjektyvusis, labiau grindžiamas vidinėmis

${ }^{64}$ Campos, P. Lawyers and Spoiled Identity. The Georgetown Journal of Legal Ethics, 2014, Vol. 73, p. 25.

65 Beliūnienè, L., et al. Viešojo intereso atpažinimo problema Lietuvos teisèje: kriterijai ir prioritetai. Vilnius: Lietuvos teisès institutas, 2015, p. 41. 
moralinėmis nuostatomis, ịsitikinimais, o visuomeninio intereso, kaip objektyviojo, paisymą lemia ìsipareigojimas elgtis teisètai. Teisinių ir moralinių nuostatų bei asmeninio ir visuomeninio interesų susidūrimas vertintinas kaip galimybé plesti teisinio ir etinio diskurso ribas.

3. Nors teisinių ir moralinių nuostatų susikirtimo problematikos klausimas dažnai lieka atviras, teisininko profesijos ir etikos santykio analizė suponuoja neišvengiamą teisès priklausomybę nuo moralès. Nepaisant pozityvistinio požiūrio, abu dèmenys - teisè ir etika - yra suvienyti kaip socialiniai elgesio reguliatoriai. Teisininko profesijos atstovas, praktikuojantis teisę, yra imanentiškai priverstas susidurti su etinemis nuostatomis, ịpareigojančiomis ir morališkai, ir teisiškai.

\section{Literatūra}

Lietuvos Respublikos Konstitucija. Valstybès žinios. 1992, Nr. 331014.

Lietuvos Respublikos Konstitucinio Teismo 1997 m. gegužès 6 d. nutarimas „Dèl Lietuvos Respublikos valdininkų įstatymo 16 straipsnio pirmosios dalies 2 punkto atitikimo Lietuvos Respublikos Konstitucijai“. Valstybès žinios. 1997, Nr. 40-977.

Lietuvos Respublikos Konstitucinio Teismo 2004 m. gegužès 25 d. nutarimas „Dèl Lietuvos Respublikos Prezidento rinkimų ìstatymo $1^{1}$ straipsnio (2004 m. gegužès $4 \mathrm{~d}$. redakcija) ir 2 straipsnio 2 dalies (2004 m. gegužès 4 d. redakcija) atitikties Lietuvos Respublikos Konstitucijai“. Valstybès žinios. 2004, Nr. 85-3094.

Lietuvos Respublikos Konstitucinio Teismo 2005 m. gegužès 13 d. nutarimas „Dèl Lietuvos Respublikos medžioklès įstatymo 7 straipsnio 2 dalies, 8 straipsnio 1, 9, 10 dalių, 13 straipsnio 2 dalies, 18 straipsnio 7 dalies ir 22 straipsnio 3, 6, 7 dalių atitikties Lietuvos Respublikos Konstitucijai“. Valstybès žinios. 2005, Nr. 63-2235.

Lietuvos Respublikos Konstitucinio Teismo 2006 m. rugsejjo $21 \mathrm{~d}$. nutarimas „Dèl Lietuvos Respublikos administracinių bylų teisenos 
istatymo 85 straipsnio 3 dalies (2000 m. rugsejjo 19 d. redakcija), 139 straipsnio 2, 3 dalių (2000 m. rugsèjo 19 d. redakcija), Lietuvos Respublikos baudžiamojo proceso kodekso 306 straipsnio (2004 m. liepos $8 \mathrm{~d}$. redakcija), 308 straipsnio (2006 m. birželio $1 \mathrm{~d}$. redakcija) 2 dalies (2002 m. kovo 14 d. redakcija), 324 straipsnio 12, 13 dalių (2002 m. kovo $14 \mathrm{~d}$. redakcija), 377 straipsnio (2004 m. liepos $8 \mathrm{~d}$. redakcija) 9 dalies (2002 m. kovo $14 \mathrm{~d}$. redakcija), 448 straipsnio 7 dalies (2002 m. kovo 14 d. redakcija), 454 straipsnio 5, 6 dalių (2002 m. kovo $14 \mathrm{~d}$. redakcija), 460 straipsnio 4, 5 dalių (2002 m. kovo 14 d. redakcija), Lietuvos Respublikos civilinio proceso kodekso 268 straipsnio 3 dalies (2002 m. vasario $28 \mathrm{~d}$. redakcija), 285 straipsnio 2, 5 dalių (2002 m. vasario $28 \mathrm{~d}$. redakcija), 286 straipsnio 1 dalies (2002 m. vasario $28 \mathrm{~d}$. redakcija), 288 straipsnio 4 dalies (2002 m. vasario $28 \mathrm{~d}$. redakcija), 289 straipsnio 2 dalies (2002 m. vasario $28 \mathrm{~d}$. redakcija), 303 straipsnio 2 dalies (2002 m. vasario $28 \mathrm{~d}$. redakcija), 320 straipsnio 2 dalies (2002 m. vasario 28 d. redakcija), 325 straipsnio 2, 3 daliu (2002 m. vasario $28 \mathrm{~d}$. redakcija), 358 straipsnio 2, 3 dalių $(2002 \mathrm{~m}$. vasario $28 \mathrm{~d}$. redakcija) atitikties Lietuvos Respublikos Konstitucijai, taip pat del pareiškèjo - Seimo narių grupès prašymo ištirti, ar Lietuvos Respublikos teismų ístatymo 119 straipsnio 2 dalies 1 punktas (2002 m. sausio 24 d. redakcija), 119 straipsnio 5 dalis (2002 m. sausio $24 \mathrm{~d}$. redakcija), 120 straipsnio (2003 m. sausio 21 d. redakcija) 1 punktas (2002 m. sausio 24 d. redakcija), Lietuvos Respublikos Prezidento 2003 m. vasario 19 d. dekretas Nr. 2067 „Dèl apygardos teismo teisèjo ịgaliojimų pratęsimo“, Lietuvos Respublikos Prezidento 2003 m. birželio 18 d. dekretas Nr. 128 „Dèl apygardų teismų skyrių pirmininkų skyrimo“ ta apimtimi, kuria nustatyta, kad Vilniaus apygardos teismo teisèjas Konstantas Ramelis skiriamas šio teismo civilinių bylų skyriaus pirmininku, neprieštarauja Lietuvos Respublikos Konstitucijai“. Valstybès žinios. 2006, Nr. 102-3957.

Lietuvos Respublikos Vyriausybės nutarimas „Dèl teisinių pareigybių sąrašo patvirtinimo“. Valstybès žinios. 2002, Nr. 82-3524. 
Barak, A. The Judge in a Democracy. New Jersey: Princeton University Press, 2006.

Berkmanas, T.; Gruodytè, E. Teisininkų etikos vertybių realumo ir modeliavimo problemos. Teises problemos. T. 85 (2014).

Bonz, B. Profesinis ugdymas ir kvalifikacija. Profesinis rengimas: tyrimai ir realijos. 1998, Nr. 1.

Beliūnienè, L., et al. Viešojo intereso atpažinimo problema Lietuvos teisejje: kriterijai ir prioritetai. Vilnius: Lietuvos teisès institutas, 2015.

Boss, J. A. Analyzing Moral Issues. California: Mayfield Publishing Company, 1999.

Campos, P. Lawyers and Spoiled Identity. The Georgetown Journal of Legal Ethics, 2014, Vol. 73.

Cotterrell, R. Teisés sociologija: ivadas. 2-asis leidimas. Kaunas: Dangerta, 1997.

Davis, M. Professionalism Means Putting Your Profession First. The Georgetown Journal of Legal Ethics. 1998. Vol. 2, No. 1.

Duquenoy, P.; Jones, S.; Blundell, B. G. Ethical, Legal and Professional Issues in Computing. London: Middlesex University Press, 2008.

Hayek, F. A. Teise, ịstatymu leidyba ir laisve. T. 2. Socialinio teisingumo miražas. Vilnius: Eugrimas, 1998.

Hegel, G. W. Teisés filosofijos apmatai. Vilnius: Mintis, 2000.

Jekentaitè, L. Teisinio ir moralinio diskursų antitezè. Jurisprudencija. 2006, [t.] 9(87).

Jibril, A.; Adelahu, Z. Legal Profession and Ethics. Teaching material. Chilot Wordpress, 2009.

Jokubaitis, A. Vertybiu tironija ir politika. Vilnius: Vilniaus universiteto leidykla, 2012.

Jokubaitis, A. Ronaldo Dworkino filosofinès revoliucijos nesèkmè. Problemos. T. 86 (2014).

Kalenda, Č. Taikomoji etika: iškilimas ir ypatybès Lietuvoje. Filosofija. Sociologija. 2009, [t.] 20, Nr. 1. 
Kanišauskas, S. Morales filosofijos pagrindai. Vilnius: Mykolo Romerio universitetas, 2009.

Kiršienė, J.; Szymanski, Ch. F. Vertybinių nuostatų ugdymo, rengiant teisininkus universitete, galimybès. Jurisprudencija. 2012, [t.] 19(4).

Kukaitis, M. Garbès negalima atimti, o tik prarasti. Justitia. 1999, Nr. 2(20).

Kuzmickas, B. Vertinimas, privalomybė, norma. Jurisprudencija. 2006, [t.] 9(87).

Lastauskienè, G. Vertybiškai neutrali teisès samprata. Jos ženklai Lietuvos teisinejje mintyje ir praktikoje. Teisés problemos. 2006, Nr. 2(52).

Lastauskienè, G. Teisès tikslai - spekuliacijos įrankis ar argumentavimo priemonè? Teise. T. 77 (2010).

Lastauskienè, G. Korektiško teisès principu taikymo prielaidos. Teise. T. 85 (2012).

Lastauskienè, G. Advokato profesija: prieštaringas jos pobūdis ir kontrolè. Jurisprudencija. 2013, [t.] 20(4).

Lyberis, A. Sinonimų žodynas. Vilnius: Lietuvių kalbos institutas, 2002.

McCollough, E. The Moral Imagination and Public Life. Raising the Ethical Question. New Jersey: Chatham House, 1991.

Mesonis, G.; Meilius, K. Moralès normos konstituciniuose teisiniuose santykiuose. Jurisprudencija. 2002, [t.] 31(23).

Mikelènienė, D.; Mikelènas, V. Teismo procesas: teisès aiškinimo ir taikymo aspektai. Vilnius: Justitia, 1999.

Lietuvos Respublikos civilinio kodekso komentaras. Kn. 1, Bendrosios nuostatos. Vilnius: Justitia, 2001.

Moore, A.; Cain, D. M.; Loewenstein, G.; Bazerman, H. M. Conflicts of Interest. Cambridge: Cambridge University Press, 2005.

Oxford English Reference Dictionary. Second Edition. Rivised. Oxford: Oxford University Press, 2003. 
Palidauskaitè, J. Etika valstybès tarnyboje: mokslinè monografija. Kaunas: Technologija, 2010.

Pearce, R. G. Teaching Ethics Seriously: Legal Ethics as the Most Important Subject in Law School. Loyola University Chicago Law Journal, Vol. 29, No. 4, 1998.

Pearce, R. G. Revitalizing the Lawyer-Poet: What Lawyers Can Learn from Rock and Roll. Widener Law Journal, Vol. 14, 2005.

Parker, Ch. A Critical Morality for Lawyers: Four Approaches to Lawyers Ethics. Monash University Law Review. Vol. 30, No. 1, 2004.

Posner, R. A. Jurisprudencijos problemos. Vilnius: Eugrimas, 2004.

Pruskus, V.; Briedis, M. Etika: vadovèlis. Vilnius: Technika, 2010.

Remley, P. Jr.; Herlihy, B. Ethical, Legal, and Professional Issues in Counseling. New Orleans: Pearson, 2013.

Simmonds, N. E. Law as a Moral Idea. Oxford: Oxford University Press, 2007.

Spruogis, E. Teisès aiškinimo probleminiai aspektai. Jurisprudencija. 2006, [t.] 8(86).

Stonkus, S. Sporto terminų žodynas. 2-asis pataisytas ir papildytas leidimas. Kaunas: Lietuvos kūno kultūros akademija, 2002.

Šlapkauskas, V. Teisés sociologijos pagrindai: vadovèlis. Vilnius: Mykolo Romerio universiteto Leidybos centras, 2004.

Wittgenstein, L. A Lecture on Ethics. The Philosophical Review I, 1965.

Gozon, M. Legal and Judicial Ethics, its Relevance Revisited. Arellano Law and Policy Review, Vol. 10, No. 1, 2009.

Gumbis, J. Teises filosofija: probleminiai aspektai. Konspektas [interaktyvus]. Prieiga per internetą: <http://www.tf.vu.lt/dokumentai/ Viesoji_teise/Paskaitu_medziaga/Teises_filosofija_probleminiai_aspektai.pdf>.

Kalesnykas, R. Teisininko profesinis rengimas: standartas, kokybė ir perspektyvos [interaktyvus]. Prieiga per internetą: <http:// www.elibrary.lt/resursai/Konferencijos/KSMK_konf_medziaga/ STRAIPSNIAI/R. Kalesnykas.pdf $>$. 
Vyriausioji enciklopedijų redakcija. Tarptautiniu žodžiu žodynas [interaktyvus]. Prieiga per internetą: <http://www.tzz.lt/p/profesija $>$.

\title{
THE LEGAL PROFESSION AND ETHICS: THE LINE BETWEEN LAW AND MORALITY
}

\author{
EGLE் RUZGYTE்
}

\section{Summary}

Keywords: the legal profession; legal ethics; morality; public interest; personal interest.

Lawyer's profession status in society - particularly significant, requiring not only high intelligence, deep legal education, operating in the interests of the public, but also the ethical behavior. Not only the professional status itself but also norms enshrined in the law obliges lawyers to follow the ethical rules. Analyzing the professional ethics of the lawyer it is important to be considered the boundary between the question of legality and morality which often remains open. From the ethical point of view, the article poses the question of the adequacy of the lawful- ness of a lawyer's behavior. The beginning of this article explains relations between lawyer's profession and ethics. In order to justify the exclusion of legal ethics, initially analysing ethics in general and professional ethics. As one of the key factors of the lawyer professional ethics, identifying legal and moral, and personal and public interests intersections. These components are often conflicting between each other and this confrontation allows to explain unethical behavior motives and consequences.

Iteikta 2017 m. rugséjo $8 d$. 